\title{
The Impact of the COVID-19 Pandemic on the Relationship Between the Asian Development Bank and Vietnam
}

\author{
Trinh Minh Duyen ${ }^{1, *}$
}

\author{
${ }^{1}$ RUDN university, Moscow, Russian Federation \\ *Corresponding author. Email: minhduyenhlu@gmail.com
}

\begin{abstract}
Vietnam has been controlling the COVID-19 pandemic dramatically. However, the COVID-19 pandemic outbreak has brought unprecedented challenges that are expected to impact Vietnam's socio-economic development in 2020 significantly and in the next year. Facing difficulties caused by the COVID-19 pandemic, the Government of Vietnam gives priority directions for socio-economic development. The foreign policy received more attention after an extended strict closure. In particular, Vietnam highly values the relationship with the Asian Development Bank (ADB). Both sides are proposing development solutions to enhance the relationship between Vietnam and ADB, to implement ADB's Development Strategy until 2030 to be more relevant to the current situation.
\end{abstract}

Keywords: COVID-19, regional bank, economy, socio-economic development, Strategy 2030, foreign

activities

\section{INTRODUCTION}

The Covid-19 pandemic has had profound effects on all aspects of all countries of the world's socio-economic life in ways that we have never known, never before there is precedent. From the economic perspective, the solutions that governments apply to countries, and the waste of resources to control diseases cause enormous losses. Economic activity is almost completely paralyzed, especially in highly open economies. In terms of human health, the COVID-19 pandemic has caused a tremendous mental health crisis and the lives of millions of people around the world.

When is a pandemic is under control and how long it will take to remedy its adverse effects is entirely dependent on how the epidemic is going and is unpredictable. Simultaneously, the world's economies are closely linked, so when a country controls a disease, it does not mean that its economy can recover, while the disease is still happening in other countries, and they still apply controls. This research identifies the effects of the COVID-19 pandemic on Vietnam, including social issues, the economy, and policy lines of the Communist Party of Vietnam, and clarifies the relationship between Vietnam and Asian Development Bank (ADB) pandemic.

\section{METHODS}

During the research process, the author used the data collection method to list the harm caused by the COVID19 pandemic and then use the analytical method to analyze the collected data. Simultaneously, the author used synthesis methods, commentary methods, and comparison methods to clarify the pandemic's severe impact on countries around the world, Vietnam, and the relationship between $\mathrm{ADB}$ and Vietnam.

\section{RESULTS AND DISCUSSION}

\subsection{The impact of the COVID-19 epidemic on Vietnam}

\subsubsection{Impacts on human life and mental health}

The COVID-19 pandemic is a new pandemic that has been affecting human health and the economy worldwide. Following its international obligation to International Health Regulations (2005), China reported to the World Health Organization (WHO) that from December 31, 2019, to January 3, 2020, There were 44 cases of pneumonia of unknown cause[1]. Based on China's initial data, the World Health Organization (WHO) believed that it is not necessary to take measures to close the border with China and does not declare a global medical 
emergency until the epidemic has cleared up outbreaks in Europe and America. Until March 11, 2020, the WHO declared the COVID-19 outbreak a global pandemic. At this time, the COVID-19 pandemic has seriously threatened the health and lives of millions of people around the world.

As of September 8, 2020, the COVID-19 pandemic has infected nearly $27,400,000$ people in 188 countries, leading to nearly 900,000 deaths and these numbers show no sign of stopping[2].

Vietnam has a $1281 \mathrm{~km}$ long border and closes economic cooperation with China[3]. Therefore, as soon as the COVID-19 epidemic broke out in China, Vietnam urgently proposed directions and measures to prevent the high risk of cross-border infections. In the first few months of 2020, when countries are tense against the COVID-19 pandemic, the Party and the entire people of Vietnam have been fighting against the epidemic very well. Within more than two months from January 23 when the first COVID-19 infection was discovered in Vietnam, there were 239 confirmed cases, and no deaths occurred[4]. On June 18, 2020 , there were only 10 infected people being treated in hospitals nationwide. However, after more than one month, from July 22, 2020, the number of new infections has increased sharply, until September 9, 2020, the number of infected people in Vietnam is 1054, the number of deaths is 35 [5].

In addition to the above figures, the more worrying thing is that the mental health and social psychology are heavily affected but cannot be statistically calculated. When the first Covid-19 infection cases in Vietnam had positive test results, the whole community was worried and uneasy. Even with a pandemic under control, grief, anxiety, and depression will continue to affect individuals and communities. The pandemic's emotional stresses, including fear of oneself or loved ones being infected or dying, fear of isolation, and loneliness when creating social distance, fear of unemployment, have a psychological impact on society. This led to the realization of the 2030 Sustainable Development Goals; specifically, the People goal (goals 1 to 6), which was already difficult before the COVID pandemic, is now even more impossible. However, compared to other countries in the world facing many difficulties, even helpless before the pandemic, Vietnam is controlling the pandemic well and is considered a model for developing countries in terms of prevention and control COVID-19[6].

\subsubsection{Impacts on the Vietnamese economy}

The COVID-19 pandemic is no longer a health problem, but affects all economies of the world: "The coronavirus disease 2019 (COVID-19) pandemic is not only stretching health systems to their limits, it is rapidly becoming a threat to the entire global economy, on a scale much greater than the 2007-08 financial crisis"[7] and "Estimates indicate that COVID-19 could cost the world more than $\$ 10$ trillion, although considerable uncertainty exists with regard to the reach of the virus and the efficacy of the policy response"[8].

First of all, countries' popular anti-epidemic measure is social isolation and distance, which causes the supply of labor to plummet, especially in areas that require direct labor involved in process manufacturing. Also, in the epidemic regions, the closure of non-essential activities, enforcement of travel restrictions causes many production activities to be halted.

Countries that have a close relationship in production activities, if one country has production delays, it will affect the production of other countries. In the current context, although China has controlled the disease, gradually restore domestic production, but now the epidemic in the EU and the US is at its peak, the disruption in the global supply chain is inevitable due to the role America and Europe in the chain are of utmost importance.

+ Direct impact: when people are advised to limit going out, the number of shoppers in shops and malls suddenly drops, causing demand to disappear from the market. Although e-commerce activities can partially overcome the above phenomenon, the effects of travel restrictions on demand are enormous. Besides, with production activities stalled, businesses temporarily stopped working or stopped working, the number of employees who had stopped working fell into an increasingly unemployed state. In the ILO preliminary assessment report titled "COVID-19 and world of work: Impacts and responses," the economic and labor crisis caused by the Covid- 19 epidemic could add 25 million people to unemployment globally.

+ Indirect impact: the impact of the COVID-19 epidemic on economic agents is very negative, causing them to have a state of postponement of consumption and investment. It is worrisome that the real economic sector's difficulties may infect the financial sector. The bankruptcy of businesses can create debt crises, the premise for disruptions in countries' financial systems.

In Vietnam, since the outbreak of the epidemic, a number of domestic and foreign research organizations have predicted the impact of the COVID-19 pandemic on the Vietnamese economy. Bloomberg (2020) forecasts that Vietnam's growth will decrease by $0.4 \%$ (data to February) [9], ADB (2020) thinks that growth will decrease by 0.5 $1 \%$, and the bad scenario could decrease to $1.5 \%$ (Report on March 10). In the report (March 31, 2020), World Bank (2020) forecasts that Vietnam's economy in 2020 is about $1.5 \%$ to $4.9 \%$ depending on the scenario. However, in the most recent report (August 6, 2020) of AMRO, Vietnam's GDP is forecast to increase by $3.1 \%$ this year and $7 \%$ next year, the highest in the region[10].

It can be seen clearly that the Covid-19 pandemic had a serious impact on Vietnam's socio-economy because its impact was multidimensional on all sectors of the socioeconomy; with three main impacts on growth, investment and trade; disruption of important production value chains; consumption decline has a big impact on services and especially tourism. Specifically, the impacts for some areas are as follows: 
- Tourism industry: The tourism industry is most severely affected by the number of tourists from abroad, as well as domestic tourism, which will be limited due to concerns about the spread of the Covid-19 epidemic. According to the Vietnam National Administration of Tourism, Vietnam's tourism industry is estimated to have a loss of between $\$ 6$ and 7 billion in the first two quarters of the year because Chinese tourists will drop 90-100\%. In addition to China, according to estimates of the authorities, the number of visitors from other countries entering Vietnam will also drop sharply, about 50\% - 60\% during the epidemic period.

- Labor and employment: According to the results of the report on the Employment and Situation in the second quarter and the first six months of the year of the General Statistics Office (GSO) announced on July 10, by the end of June 2020, there are 30.8 million people aged 15 and over were negatively affected by the Covid-19 epidemic, including job loss, reduced working hours, reduced income. The impact of income reduction accounts for the highest proportion, with $57.3 \%$ of the total affected people (17.6 million people, respectively). The service sector was most affected by the Covid-19 outbreak, with $72.0 \%$ of workers affected. Next is the industry and construction sector, with $67.8 \%$ of workers affected; The rate of affected workers in the agriculture, forestry, and fishery sector is $25.1 \%$. Simultaneously, the labor force aged 15 and over in the second quarter of 2020 is 53.1 million people, down 2.2 million people from the previous quarter and 2.4 million people from the same period last year. 2020 is the year that recorded a record deep decrease in the workforce ever.

\subsubsection{Impact on the direction and strategy of the country development}

For each period of the COVID-19 pandemic, the Party and the State of Vietnam have introduced corresponding policies and paths to suit each stage. When the first case is confirmed, the policy response focuses on the threat assessment, along with the development of guidelines and plans as preventive measures for the coming war on the new disease detect. The Politburo requires the Party committees, authorities, departments, sectors, and mass organizations to focus on disease prevention and control with the highest sense of responsibility, determined not to let epidemic outbreaks occur, and at the same time perform their duties urgent services, supporting the business community, maintaining production and business, taking care of the people, proactively preparing economic recovery plans.

On March 30, 2020, General Secretary and President Nguyen Phu Trong issued a call for our compatriots, comrades, and soldiers throughout the country and our compatriots abroad to unite, unify their will and action, drastically and effectively implemented the guidelines of the Party and State, resolutely won the COVID-19 pandemic.
Since the discovery of the first case until now, a series of directives by the Prime Minister to implement pandemic prevention measures:

- On February 1, 2020, Prime Minister Nguyen Xuan Phuc issued Decision 173 / QD-TTg on declaring acute respiratory infections caused by a new strain of Coronavirus, and at the same time, decided to tighten the border, Aviation permit revocation, and visa restrictions[11].

- On March 31, 2020, Prime Minister Nguyen Xuan Phuc issued Directive 16 / CT-TTg on the implementation of urgent measures to prevent and control COVID-19 epidemics.

- On April 1, 2020, Prime Minister Nguyen Xuan Phuc signed Decision 447 / QD-TTg on the publication of COVID-19 nationwide, replacing the previous decision to announce the epidemic on January 1. 2 years 2020[12].

- $\quad$ On April 25, the Prime Minister issued Directive 19 / CT-TTg to continue measures to prevent and control the COVID-19 epidemic "in the new situation" [13]

When the disease broke out again, Directive No. 16 / CTTTg dated March 31, 2020, and Directive No. 19 / CTTTg dated April 24, 2020, of the Prime Minister were reimplemented. From July 31, 2020, Vietnam began to confirm these deaths. The total number of infections is more than 1000 people. According to the Newsletter of the National Steering Committee for Disease Control and Prevention dated September 22, there is no new case of COVID-19 in Vietnam. Up to now, also 20 days, Vietnam has not recorded cases of infection in the community[14].

\subsubsection{Impacts on foreign activities}

So far, the pandemic continues to prolong, political and diplomatic relations between countries and partners worldwide will be significantly affected epidemic zones, and citizens of countries affected by the epidemic have had a negative impact on political and diplomatic relations between countries. Developments related to epidemics can make relationships between nations, peoples, regions, and continents more "sensitive". This problem is difficult to solve in a short time due to the differences in policies, policies, and measures to handle crisis and fight epidemics in each country. Solving this problem is even more difficult than solving economic problems.

Recognizing this, Vietnam has cooperated closely with the United Nations' countries and organizations, especially the WHO, to research, implement, and complete treatment regimens, vaccine research, etc.

Vietnam has also made great efforts and creativity in foreign affairs. The Chairman of the National Assembly issued a letter to the ASEAN Inter-Parliamentary Council 
(AIPA) member parliaments calling for joint action against the Covid-19 epidemic. As the Chair of ASEAN 2020, the Prime Minister issued a Declaration of ASEAN President on ASEAN's joint response to the Covid-19 epidemic, successfully chaired the ASEAN Special Summit and the Online Summit route ASEAN +3 on cooperation in epidemic prevention and control.

With the spirit of sharing, responsibility, and proactive integration, Vietnam has had many activities to support and cooperate with 20 countries and international organizations, affirming its role as an active and responsible member international community and strengthening relations with other countries and partners. Thus, with the preeminence of the political system, Vietnam, together with the consensus and solidarity of the entire people and the entire army, the epidemic prevention and control work has achieved good results, Vietnam has repelled and controlled get epidemic. At the same time, there were timely policies to support businesses and people to overcome the difficulties of the COVID-19 pandemic; activities of the socio-economic life are being restored; The socio-economic situation has had positive changes; Being highly appreciated by the international community, the people increasingly believe in the leadership of the Party and State and the direction of the Government.

\subsubsection{Policy recommendations in the coming time}

In the last months of 2020 and the coming time, together with doing well the disease prevention and fighting, the Government has directed the synchronous and drastic implementation of tasks and solutions for socio-economic recovery and development, in which build a number of specific mechanisms and policies in the new situation, submit to competent authorities for the decision to soon implement in the context of many difficulties and challenges.

Firstly, continue to seriously implement the guiding documents of the Secretariat, the Standing Secretariat, and the Prime Minister, the unified direction and administration of the National Steering Committee on epidemic prevention and control Covid-19.

Second, focus on disease prevention and control, perfecting plans and scenarios for epidemic control at different scales; fully satisfy the conditions on material foundations, equipment, materials, and human resources to prevent and fight the epidemic in a strong outbreak situation.

Thirdly, promptly and transparently communicate and inform people about the epidemic situation, strictly handle those who give false information, affecting the epidemic prevention and control.

Fourthly, encourage the people and businesses to promote patriotism, compassion, and social responsibility, join in epidemic prevention and control, support functional forces to fulfill their tasks. Fifth, continue to direct the building of scenarios for economic and social development consistent with the epidemic situation, formulating and implementing a number of specific mechanisms and policies for socio-economic recovery and development. Sixth, to well implement foreign and diplomatic activities, especially ASEAN diplomacy activities, regularly exchange and share experiences, cooperate in epidemic prevention and control, timely communication, so that countries can understand the undertakings and policies of Vietnam in the epidemic prevention and control process.

\subsection{The role of the Asian Development Bank to Vietnam in the COVID-19 translation}

As soon as a pandemic broke out, an issue of concern was the response of international organizations to the COVID19 pandemic. This pandemic has posed enormous political challenges for global and institutional cooperation. However, international organizations play a key role in the global response and are still carrying out important missions. Key organizations are coordinating international efforts, including air transportation supplies and medical personnel, managing pandemic cross-border research, and sharing essential information and initiating funds aid.

First, it can be said that the WHO has been at the center of the fight against the new Coronavirus since the first outbreak was reported in China. WHO has launched a War Preparedness and Response Plan and is taking action in countries around the world on prevention, surveillance, prevention, treatment, coordination, and more. Regarding financial calls, "The WHO has called for at least US \$ 675 million to fund critical response efforts in countries most in need of help through April 2020"[15]. For Vietnam, the WHO has supported Viet Nam to strengthen the capacity of laboratory testing for infectious diseases as required by the International Health Regulations (IHR) (2005).

As financial institutions, major monetary funds in the world, the International Monetary Fund (IMF) and the World Bank (WB) are also expected to respond promptly and effectively:"The G20 countries envisaged the two leading global financial institutions, the International Monetary Fund (IMF) and the World Bank, playing a central role in supporting these countries" [16]. In fact, the IMF and the WB have also supported the anti-epidemic countries such as The WB has approved the \$250 million package to support the Indonesian emergency response program, and the IMF has approved the "Contingent credit" totaling 11 billion USD for Peru, with a disbursement period of 3 years, also with the purpose of responding to the negative economic impacts of Covid-19, etc. According to the report, "What will a new normal situation in Vietnam be? The economic impact of COVID19 " proposed by the WB to the Government of Vietnam is to focus on fiscal policy, a traditional tool to stimulate economic recovery practice.

The International Organization for Migration (IOM) has also been adjusting existing capacities and resources to meet the needs of migrants during the COVID-19 
pandemic. In addition, IOM Viet Nam joined the United Nations working group on the socio-economic impacts of COVID-19, ensuring that both domestic and international migrants were considered.

In recent years, the Asia-Pacific region has been dynamically developing, playing a central role in the world economic linkage, and at the same time, there are important changes in both economic and political terms. As an Asia-Pacific regional financial institution, the Asian Development Bank (ADB) is committed to achieving a prosperous, inclusive, resilient, and sustainable Asia and Pacific region to maintain efforts to eradicate extreme poverty. However, the prolonged COVID-19 pandemic is the biggest adverse risk to the region's growth prospects in 2020 and the following year.

World Bank (2020) predicts that the growth of East Asia and Pacific economies will range from $2.1 \%$ to $-0.5 \%$ recession in 2020, depending on different scenarios. However, these economies will recover strongly in 2021[17]. According to its Asian Development Outlook Update (ADO) 2020, ADB projects a negative $0.7 \%$ growth in the gross domestic product (GDP) for developing Asia this year - marking the negative growth since the early $1960 \mathrm{~s}[18]$. Growth will reach $6.8 \%$ in 2021 , partly due to a relative measure of 2020's low growth.

On March 18, the Asian Development Bank (ADB) announced an initial \$ 6.5 billion response to the COVID19 pandemic[19]. This assistance package tripled on April 13 , to $\$ 20$ billion, and ADB approved faster measures to provide rapid and flexible support. The new fund helps developing member country governments overcome the cyclical crisis to mitigate the impact of the COVID-19 pandemic, targeted at the poor and vulnerable. In addition, this fund will continue to be deployed to address the needs of medical equipment for member countries and the private sector[20]. Not only that, ADB did it in close coordination with international organizations, including the International Monetary Fund, WB Group, WHO, United Nations Children's Fund, and other United Nations agencies, with the broader global community.

Thus, ADB has been working against COVID-19 in three aspects:

- Quick support for member states;

- $\quad$ Support for the private sector includes loans and guarantees provided to financial institutions to stimulate trade and supply chains;

- International cooperation: closely coordinate with other international organizations.

For Vietnam, $\mathrm{ADB}$ is one of the leading donors of financial finance, technical assistance, and advisory: "Since 1966, ADB has provided $\$ 16.7$ billion in cumulative assistance for Viet Nam. Cumulative loan and grant disbursements to Viet Nam amount to \$11.1 billion"[21]. In 2019, the ADB Country Operations Plan had a National Operational Plan (COBP) 2020-2022 for Vietnam. In which priority is given to the implementation of the 5-year socio-economic development plan from 2016 to 2020 of Vietnam and the assistance of ADB to implement this plan in the country partnership strategy (CPS) in 2016 -2020.

CPS focuses on inclusive and environmentally sustainable economic growth by promoting job creation and competitiveness, strengthening infrastructure construction and service delivery, equalizing, improving environmental sustainability, and responding to climate change. CPS priorities remain valid in the preparation of the new CPS. This Country Work Plan also incorporates the relevant elements of ADB's Strategy 2030, while looking at increasing public debt and the Government's response by adopting tighter terms in the use of official development assistance.

After the pandemic happened, it affected the socioeconomy of Vietnam, affecting these strategies. It can be said that the progress of completing ADB's Strategy 2030 and Vietnam's action programs to achieve the above goal is considered impossible. However, to resolve the immediate problem, ADB has always been ready to assist Vietnam in the prevention of the COVID-19 pandemic. In addition, ADB gave policy advice to Vietnam to respond to the impact of the COVID-19 pandemic, and ADB proposed a COVID-19 response loan for Vietnam.

Also, in its most recent Asian Development Outlook (ADO) 2020 report, ADB forecasts that Vietnam's economy will maintain a positive growth rate of $1.8 \%$ in 2020 and an increase in the level of $6.3 \%$ in 2021[22]. After this pandemic, the socio-economic situation of Vietnam will have many changes; ADB will develop a new country partnership strategy to suit the new situation of Vietnam. ADB will consider strategies and funding to support Vietnam in detail. The new strategy will incorporate priorities of Viet Nam's Socio-Economic Development Plan 2021-2025 and ADB's Strategy 2030. ADB assists the Government of Viet Nam through financing for important infrastructure projects, mobilize non-refundable aid and ordinary loans, using ADB capital to attract private sources, and other technical assistance funds. In addition to supporting the State, ADB can also mobilize capital for innovation and knowledge.

Vietnam has made efforts to improve the legal framework on public investment and public debt management through the development of important legal documents for ministries, localities, and donors to implement and mobilize and use foreign loans transparently and effectively. Vietnam has always strictly and transparently implemented its commitments with ADB. Currently, Vietnam is working to develop the Orientation for the period 2021-2025 in association with the socio-economic development plan for the period 2021-2025 as a basis for ministries to coordinate with ADB in selecting programs, project-specific promotes efficiency in bilateral cooperation. 


\section{CONCLUSION}

Currently, Vietnam has been implementing two goals: both to fight against the COVID - 19 epidemic and to ensure economic growth. However, the epidemic COVID19 in the world is still complicated and unpredictable, the negative impacts of the epidemic on all aspects of the socio-economic life continue to persist and cannot be fully assessed. Therefore, it continues to affect international cooperation in general and the relationship between Vietnam and $\mathrm{ADB}$ in particular. In addition, the comprehensive settlement of post-pandemic issues will also face many difficulties, but Vietnam and ADB have always trusted and cooperated with each other.

\section{REFERENCES}

[1] World Health Organization. Novel

Coronavirus (2019-nCoV) Situation Report-1. WHO;

2020. Available online:

https://www.who.int/docs/default-

source/coronaviruse/situation-reports/20200121-sitrep-

1-2019-ncov.pdf?sfvrsn $=20$ a99c10_4, (accessed on

February 28, 2020)

[2] Figures for 09 September; Johns Hopkins

University Center for Systems Science Engineering

Dashboard, Available online:

https://gisanddata.maps.arcgis.com/apps/opsdashboard/i

ndex.html\#/bda7594740fd40299423467b48e9ecf6

[3] Central Intelligence Agency. The World

Facebook-Vietnam. Available online:

https://www.cia.gov/library/publications/the-worldfactbook/geos/vm.html (accessed on 16 March 2020)

[4] Ministry of Health. Information Page about COVID-19 Respiratory Disease Outbreak. Available online: https://ncov.moh.gov.vn/ (accessed on 31 March 2020)

[5] Ministry of Health. Information Page about COVID-19 Respiratory Disease Outbreak. Available online: https://ncov.moh.gov.vn/ (accessed on 09 September 2020)

[6] IMF (2020), Vietnam's Success in Containing COVID-19 Offers Roadmap for Other Developing Countries. Available online: https://www.imf.org/en/News/Articles/2020/06/29/na06 2920-vietnams-success-in-containing-covid19-offersroadmap-for-other-developing-countries (accessed on 09 September 2020)
[7] A. Kentikelenis, D. Gabor, I. Ortiz, T. Stubbs, M. McKee, D. Stuckler. Softening the blow of the pandemic: Will the International Monetary Fund and World Bank make things worse?.The Lancet Global Health, 8 (2020), pp. e758-759. DOI: https://doi.org/10.1016/S2214-109X(20)30135-2

[8] F. Ahmed, N. Ahmed, C. Pissarides, J. Stiglitz, Why inequality could spread COVID-19. The Lancet Public Health, 5 (5) (2020), Article e240, pp. 51-63. DOI: https://doi.org/10.1016/S2468-2667(20)30085-2

[9] Bloomberg (2020), Vietnam's GDP Growth Slows in First Quarter as Virus Hits. Available online: https://www.bloomberg.com/news/articles/2020-0327/vietnam-s-gdp-growth-slows-in-first-quarteramidvirus-spread (accessed on 09 September 2020)

[10] AREO (2020, Update of the ASEAN 3 Regional Economic Outlook (AREO) - August 2020.

Available online: https://www.amro-asia.org/update-ofthe-asean3-regional-economic-outlook-areo-august2020/ (accessed on 09 September 2020)

[11] Vietnam News Agency. Vietnam declares novel coronavirus epidemic. Available online:https://web.archive.org/web/20200201121402/ht tps://en.vietnamplus.vn/vietnam-declares-novelcoronavirus-epidemic/168021.vnp (accessed on 30 July 2020)

[12] Vietnam net. Thủ tướng công bố dịch Covid-19 trên toàn quốc. Available online:

https://vietnamnet.vn/vn/thoi-su/thu-tuong-cong-bodich-covid-19-tren-toan-quoc-629894.html (accessed on 15 August 2020)

[13] Cổng thông tin điện tử Bộ Y tế. Thủ tướng chỉ thị tiếp tục các biện pháp phòng, chống dịch COVID-19 trong tình hình mới. Available online:

https://moh.gov.vn/hoat-dong-cua-lanh-dao-bo/ /asset_publisher/TW6LTp1ZtwaN/content/thu-tuongchi-thi-tiep-tuc-cac-bien-phap-phong-chong-dichcovid-19-trong-tinh-hinh-moi (accessed on 15 August 2020)

[14] Ministry of Health. Information Page about COVID-19 Respiratory Disease Outbreak. Available online: https://ncov.moh.gov.vn/ (accessed on 22 September 2020).

[15] McKibbin, Warwick J. and Vines, David, Global Macroeconomic Cooperation in Response to the COVID-19 Pandemic: A Roadmap for the G20 and the 
IMF (July 15, 2020). Forthcoming in 'The Economics of the COVID-19 Pandemic', volume 36(Supplement) of the Oxford Review of Economic Policy, July 2020, CAMA Working Paper No. 68/2020, Available at SSRN: https://ssrn.com/abstract $=3651586$ or DOI: http://dx.doi.org/10.2139/ssrn.3651586

[16]A. Kentikelenis, D. Gabor, I. Ortiz, T. Stubbs, M. McKee, D. Stuckler. Softening the blow of the pandemic: Will the International Monetary Fund and World Bank make things worse? The Lancet Global Health, 8 (2020), pp. e758759.

DOI: https://doi.org/10.1016/S2214-109X(20)30135-2

[17] World Bank (2020), East Asia and Pacific in the Time of COVID-19, World Bank East Asia and Pacific Economic Update. Available online: https://www.worldbank.org/en/region/eap/publication/e astasia-pacific-economic-update> (accessed on April 10 2020)

[18] ADB (2020), Asian Development Outlook 2020 Update: Wellness in Worrying Times. DOI: http://dx.doi.org/10.22617/FLS200256-3

[19] ADB (2020), ADB Announces \$6.5 Billion Initial Response to COVID-19 Pandemic. Available online: https://www.adb.org/news/adb-announces-6-5-billioninitial-response-covid-19-pandemic

[20] ADB (2020), ADB Triples COVID-19 Response Package to \$20 Billion. Available online:

https://www.adb.org/news/adb-triples-covid-19response-package-20-billion

[21] ADB (2020), Asian Development Bank and Viet Nam: Fact Sheet. Available online:

https://www.adb.org/sites/default/files/publication/2781 3/vie-2019.pdf

[22] ADB (2020), Asian Development Outlook 2020 Update: Wellness in Worrying Times. DOI: http://dx.doi.org/10.22617/FLS200256-3 